\title{
Analisis Fisiko-Kimia Pati Buah Sukun (Artocarpus altilis) Muda dan Mengkal Asal Kabupaten Bone Sulawesi Selatan sebagai Kandidat Bahan Tambahan Sediaan Tablet
}

\author{
Aliyah Aliyah, Latifah Rahman, Dwi Pratiwi, dan Nurjumiah \\ Program Studi Farmasi, Fakultas Farmasi, Universitas Hasanuddin, Makassar, Indonesia \\ Korespondensi: Aliyah \\ Email: aliyahputranto@yahoo.co.id
}

Submitted: 27-05-2021, Revised: 07-06-2021, Accepted: 30-06-2021

\begin{abstract}
ABSTRAK: Buah sukun (Artocarpus altilis) merupakan salah satu sumber karbohidrat tinggi yang dapat diolah menjadi pati dan memiliki multifungsi sebagai bahan tambahan dalam industri farmasi. Penelitian ini bertujuan untuk menentukan sifat fisiko-kimia pati buah sukun dan untuk mengetahui fungsinya sebagai bahan tambahan dalam sediaan tablet konvensional. Pati diperoleh dari buah sukun muda dan mengkal menggunakan metode dekantasi. Pati yang diperoleh dikeringkan dan dilakukan analisis fisika meliputi pH, kadar air, kerapatan sejati, kerapatan nyata, kerapatan mampat, kecepatan alir, dan viskositas, serta analisis kimia meliputi kadar amilosa dan amilopektin. Hasil penelitian menunjukkan rendemen pati buah sukun muda dan mengkal masing-masing 4,3\% dan $8,93 \%$, berupa serbuk halus berwarna putih, tidak berasa, dan berbau khas sukun, bentuk speris tidak beraturan, dengan ukuran partikel rata-rata 26,06 $\mu \mathrm{m}$ dan 5,69 $\mu \mathrm{m}$. Analisis sifat fisika memperlihatkan bahwa kedua pati memiliki $\mathrm{pH}$, kadar air, dan kerapatan yang sesuai pustaka, sifat alir yang buruk, dengan viskositas yang memperlihatkan bahwa semakin tinggi konsentrasi pati semakin meningkat viskositasnya; sedangkan hasil analisis kimia menunjukkan bahwa kedua pati memiliki kadar amilosa yang lebih tinggi dibandingkan kadar amilopektinnya, sehingga direkomendasikan untuk digunakan sebagai bahan penghancur sediaan tablet konvensional.
\end{abstract}

Kata kunci: analisis fisiko-kimia; buah sukun muda; buah sukun mengkal; pati

ABSTRACT: Breadfruit (Artocarpus altilis) is one of the sources of high carbohydrate which can be processed into starch and has multifunctionality as an additive in the pharmaceutical industry. This study aimed to investigate the physicochemical properties of breadfruit starch and to evaluate its function as an additive in conventional tablet dosage forms. Starch was obtained from immature and unripe mature breadfruits using the decantation method. Afterwards, the obtained starch was dried and physical analysis was carried out including $\mathrm{pH}$, moisture content, true density, bulk density, tap density, flow rate, and viscosity, as well as chemical analysis including amylose and amylopectin content. The results exhibited that the yield obtained from immature and unripe mature breadfruits were $4.3 \%$ and $8.93 \%$, respectively, in the form of a white fine powder, tasteless, and with a characteristic odor of breadfruit, irregular spherical shape, with the average particle sizes of $26.06 \mu \mathrm{m}$ and $5.69 \mu \mathrm{m}$, respectively. Analysis of physical properties revealed that both starches possessed $\mathrm{pH}$, moisture content, and density according to the requirement in the literature, poor flowability, with viscosity indicating that the higher the starch concentration, the higher the viscosity. The results of chemical analysis depicted that both starches had higher amylose content in comparison with their amylopectin contents, therefore, it was recommended that these starches could be potentially used as a disintegrant for conventional tablet preparations.

Keywords: immature breadfruits; physico-chemical analysis; starch; unripe mature breadfruits 


\section{Pendahuluan}

Sulawesi Selatan merupakan salah satu provinsi penghasil sukun terbanyak setelah Jawa Tengah, Jawa Barat, dan Jawa Timur [1]. Salah satu sentra produksi sukun di Sulawesi Selatan adalah Kabupaten Bone, yang telah melakukan pengembangan sukun secara serius sebagai strategi percepatan penganekaragaman pangan dalam menunjang kecukupan pangan [2].

Sukun (Artocarpus altilis) dikenal sebagai starchy fruit atau buah penghasil tepung atau pati, sehingga dapat dimanfaatkan sebagai bahan pangan dan bahan tambahan (eksipien) dalam industri farmasi $[3,4]$. Buah sukun sudah mampu menghasilkan pati meskipun usia buah masih muda. Konsentrasi pati dalam buah sukun akan semakin meningkat saat buah mulai dewasa atau mengkal, namun konsentrasi akan menurun saat buah memasuki fase sangat matang [5]. Khususnya sukun mengkal, setelah pemetikan akan mengalami proses metabolisme sehingga pada hari ke 7-8 menjadi matang [6]. Sukun matang akan memiliki rasa yang semakin manis, tetapi teksturnya menjadi lembek (lunak sedikit berair). Salah satu upaya untuk meningkatkan daya guna dan nilai ekonominya yaitu dengan cara pengolahan lain seperti pembuatan tepung atau pati sukun $[2,6]$.

Dalam industri farmasi, pati merupakan eksipien yang multifungsi, digunakan sebagai pengental, pengikat, pengisi, dan penghancur tablet [7]. Namun, sebelum digunakan sebagai bahan tambahan pati harus dikarakterisasi terlebih dahulu dengan menguji sifat fisika maupun kimianya, karena sifat fisiko-kimia secara langsung mempengaruhi sifat fungsional pati itu sendiri [8].

Adebayo et al. [9] telah meneliti pati sukun sebagai penghancur tablet dibandingkan dengan pati jagung British Pharmacopoeia (BP) dalam formulasi tablet parasetamol. Hasil penelitian menunjukkan bahwa sebagai penghancur, pati sukun menghasilkan waktu hancur tablet dan disolusi obat yang cepat.
Berdasarkan hal tersebut, maka dilakukan penelitian uji sifat fisiko-kimia pati dari buah sukun muda dan mengkal asal Kabupaten Bone, dengan tujuan untuk mengetahui karakteristik kedua pati tersebut agar dapat menjadi bahan tambahan pada sediaan farmasi, khususnya sediaan tablet konvensional.

\section{Metode}

\subsection{Alat dan bahan}

Alat-alat yang digunakan adalah blender (Kirin $^{\circledR}$ ), timbangan analitik (Ohaus ${ }^{\circledR}$ ), timbangan digital (Sartorius ${ }^{\circledR}$ ), oven $\left(\right.$ Memmert $^{\circledR}$ ), krus silikat, moisture balance (Mettler Toledo ${ }^{\circledR}$ ), tanur listrik (Lab $\mathrm{Tech}^{\circledR}$ ), pH meter $\left(\mathrm{PL}-700^{\circledR}\right)$, flow tester, vortex, magnetic stirrer, sentrifuse, piknometer, mikroskop optik (Olympus ${ }^{\circledR}$ ), tap density tester (TDT-2-H), spektrofotometer UV-Vis (Agilent ${ }^{\circledR}$ ), viscometer (Brookfield RVT), tangas air, ayakan mesh 80, dan alat-alat gelas (Pyrex ${ }^{\circledR}$ ).

Bahan-bahan yang digunakan adalah buah sukun muda umur 1 sampai 2 bulan dan buah sukun mengkal umur lebih dari 2 bulan hingga 3 bulan, diperoleh dari Kabupaten Bone Sulawesi Selatan, amilosa baku (Sigma-Aldrich ${ }^{\circledR}$ ), glukosa baku $\left(\right.$ Merck $\left.^{\circledR}\right)$, natrium metabisulfit $\left(\operatorname{Merck}^{\circledR}\right)$, parafin cair, iodum, kalium iodida, $\mathrm{NaOH}\left(\mathrm{Merck}^{\circledR}\right), \mathrm{HCl}$ $\left(\right.$ Merck $\left.^{\circledR}\right)$, asam perklorat $\left(\right.$ Merck $\left.^{\circledR}\right)$, fenol, asam sulfat $\left(\right.$ Merck $\left.^{\circledR}\right)$, etanol $95 \%\left(\right.$ Onemed $\left.^{\circledR}\right)$, dan aquadest $\left(\right.$ Onemed $^{\circledR}$ ).

\subsection{Pengolahan sampel}

Buah sukun dikupas kulitnya, dipotong-potong kecil, dan dicuci, lalu direndam dalam larutan natrium metabisulfit $0,5 \% \mathrm{~b} / \mathrm{v}$ selama 30 menit, kemudian ditiriskan dan diblender dengan penambahan air. Selanjutnya diperas menggunakan kain saring. Hasil perasan didiamkan selama 24 jam hingga pati mengendap, lalu didekantasi. Pati yang diperoleh dikeringkan di oven pada suhu $50^{\circ} \mathrm{C}$ selama 5 jam, kemudian diayak dengan ayakan mesh 80 . 


\subsection{Analisis fisika pati sukun}

\subsubsection{Penetapan rendemen}

Rendemen pati dihitung dengan menggunakan rumus sebagai berikut [10]:

$$
\text { Rendemen }=\frac{\text { Bobot pati }(g)}{\text { Bobot sukun }(g)} \times 100 \%
$$

\subsubsection{Organoleptis}

Pengamatan organoleptis pati meliputi tekstur, warna, bau, dan rasa [7].

\subsubsection{Bentuk dan ukuran partikel [11]}

Pati sebanyak $10 \mathrm{mg}$ disuspensikan dengan $10 \mathrm{ml}$ etanol 70\% dan diamati bentuknya menggunakan mikroskop optik, lalu dihitung ukuran partikelnya sebanyak 300 partikel. Rata-rata ukuran partikel dihitung dengan persamaan sebagai berikut:

$$
\text { Diameter rata }- \text { rata }=\frac{\sum n d}{\sum n}
$$

Dimana, $\mathrm{n}=$ jumlah partikel dan $\mathrm{d}=$ diameter tengah.

\subsubsection{Penetapan $\mathrm{pH}$}

Pati sukun ditimbang $5 \mathrm{~g}$, lalu didispersikan dengan $20 \mathrm{ml}$ aquadest, didiamkan selama 15 menit, kemudian diukur pHnya [12].

\subsubsection{Penetapan kadar air}

Penetapan kadar air dilakukan dengan alat moisture balance [13].

\subsubsection{Penetapan kerapatan [11, 14]}

\section{a. Kerapatan sejati}

Piknometer kosong yang diketahui volumenya $\left(\mathrm{v}_{\mathrm{p}}\right.$ ) ditimbang bobotnya (a g), kemudian diisi penuh dengan parafin cair dan ditimbang kembali (b g), sehingga diperoleh kerapatan parafin (g/ml) sebagai berikut:

$$
\rho \text { parafin }=\frac{b-a}{v_{p}}
$$

Sebanyak $1 \mathrm{~g}$ pati dimasukkan ke dalam piknometer kosong, lalu ditimbang bobotnya (c g). Dimasukkan parafin cair ke dalam piknometer hingga penuh dan ditimbang kembali (d g), se- hingga diperoleh kerapatan sejati $(\mathrm{g} / \mathrm{ml})$ sebagai berikut:

$$
\rho \text { sejati }=\frac{(c-a) x \rho_{p}}{(c+b)-(a+d)}
$$

\section{b. Kerapatan nyata, kerapatan mampat, kadar pemampatan, dan rasio Hausner}

Penentuan kerapatan nyata, kerapatan mampat, kadar pemampatan, dan rasio Hausner dilakukan dengan tap density tester. Pati ditimbang $25 \mathrm{~g}$, dimasukkan ke dalam gelas ukur $100 \mathrm{ml}$, dicatat volumenya $\left(\mathrm{v}_{\mathrm{o}}\right)$. Kerapatan nyata dihitung dengan persamaan sebagai berikut:

$$
\rho \text { nyata }=\frac{\text { bobot pati }}{V_{0}}
$$

Selanjutnya dilakukan pengetukan dengan alat. Volume pada ketukan ke-10, 500, dan 1250 kali dicatat, lalu dihitung kerapatan mampat, kadar pemampatan, dan rasio Hausner dengan rumus sebagai berikut:

$$
\rho \text { mampat }=\frac{\text { bobot pati }}{\text { volume pada ketukan ke }-n}
$$

Kadar pemampatan $=\frac{V_{0}-V_{\text {mampat }}}{V_{0}} \times 100 \%$

$$
\text { Rasio Hausner }=\frac{V_{0}}{V_{\text {mampat }}}
$$

\subsubsection{Penetapan laju alir dan sudut istirahat [15]}

Pati sebanyak $25 \mathrm{~g}$ dimasukkan ke dalam corong pada flow tester. Lubang bawah corong ditutup, kemudian tutup lubang dibuka bersamaan dengan dijalankannya stopwatch. Waktu yang dibutuhkan pati untuk melewati alat tersebut dicatat, sedangkan gundukan yang terbentuk digunakan untuk menentukan sudut istirahat, menggunakan rumus sebagai berikut:

$$
\tan \theta=\frac{\text { tinggi massa serbuk }}{\text { jari }- \text { jari serbuk }}
$$

\subsubsection{Penetapan viskositas [7]}

Pati ditimbang saksama 2,5 g; 5 g; dan 7,5 g, kemudian masing-masing ditambah dengan 50 
ml aquadest, dipanaskan sambil diaduk hingga membentuk gel, lalu didinginkan dan diukur viskositasnya dengan viscometer (Brookfield ${ }^{\circledR}$ ).

\subsection{Analisis kimia pati sukun}

\subsubsection{Penetapan kadar pati total [16, 17]}

\section{a. Penyiapan larutan pati}

Pati $100 \mathrm{mg}$ dimasukkan ke dalam tabung sentrifus, dibasahi dengan $1 \mathrm{ml}$ etanol $80 \%$, lalu ditambahkan $5 \mathrm{ml}$ aquadest dan $10 \mathrm{ml}$ etanol $80 \%$ hangat, disentrifus pada kecepatan 4.000 rpm selama 5 menit. Supernatan dibuang dan endapan dimasukkan ke dalam labu tentukur, lalu ditambahkan $13 \mathrm{ml}$ larutan asam perklorat $52 \%$ dan $9 \mathrm{ml}$ aquadest, didiamkan 1 jam, dan dicukupkan volumenya dengan aquadest hingga $100 \mathrm{ml}$. Selanjutnya dari larutan ini dibuat larutan dengan konsentrasi $100 \mathrm{bpj}$.

\section{b. Penetapan kadar pati total}

Larutan pati diambil saksama sebanyak $1 \mathrm{ml}$, kemudian ditambahkan $1 \mathrm{ml}$ aquadest, $1 \mathrm{ml}$ laru$\tan$ fenol 5\%, dan $5 \mathrm{ml} \mathrm{H}_{2} \mathrm{SO}_{4}$ pekat, dihomogenkan dan didiamkan selama 10 menit. Kemudian diukur serapannya dengan spektrofotometer UVVis pada panjang gelombang maksimum glukosa (484 $\mathrm{nm}$ ), lalu dihitung kadar pati totalnya sebagai kadar glukosa dengan bantuan kurva baku.

\subsubsection{Penetapan kadar amilosa dan amilopektin}

Kadar amilosa ditetapkan dengan cara sebagai berikut: pati ditimbang saksama $20 \mathrm{mg}$, ditambahkan $1 \mathrm{ml}$ etanol 95\%, dan $9 \mathrm{ml}$ larutan $\mathrm{NaOH} 1 \mathrm{~N}$, dikocok hingga pati larut dan dicukupkan volumenya dengan aquadest hingga 100 ml. Dari larutan ini diambil sebanyak 2,5 ml, dimasukkan ke dalam labu tentukur, ditambahkan $1 \mathrm{ml}$ larutan $\mathrm{HCl}$ 0,1 $\mathrm{N}$ dan 0,1 ml larutan Iodin, kemudian dicukupkan volumenya dengan aquadest hingga $10 \mathrm{ml}$. Selanjutnya larutan diukur serapannya dengan spektrofotometer pada panjang gelombang maksimum amilosa (620 nm) dan dihitung kadar amilosa pati dengan bantuan kurva baku $[18,19]$. Kadar amilopektin dihitung dengan cara kadar pati total dikurangi dengan kadar amilosa.

\section{Hasil dan pembahasan}

Sukun merupakan salah satu buah penghasil pati yang memiliki manfaat dalam bidang pangan dan farmasi [3, 4]. Dalam industri farmasi, pati dimanfaatkan sebagai bahan tambahan (eksipien), khususnya dalam sediaan tablet, yaitu sebagai pengikat, pengisi, dan penghancur tablet $[7,20$, 21]. Untuk dapat digunakan sebagai eksipien, maka pati harus diketahui terlebih dahulu sifat fisiko-kimianya, karena sifat fisiko-kimia secara langsung mempengaruhi sifat fungsional pati itu sendiri [8].

Untuk memperoleh pati dari buah sukun dilakukan dengan metode dekantasi, dan terhadap pati yang diperoleh dilakukan analisis fisika meliputi penetapan $\mathrm{pH}$, kadar air, kerapatan, viskositas dan analisis kimia meliputi kadar amilosa dan amilopektin. Hasil analisis fisika dapat dilihat pada Tabel 1, sedangkan hasil analisis kimia dapat dilihat pada Tabel 2.

\subsection{Hasil analisis fisika pati sukun}

\subsubsection{Rendemen}

Hasil rendemen buah sukun muda diperoleh 4,3\%. Hasil ini lebih kecil dari buah sukun mengkal, yaitu $8,93 \%$. Hal ini sesuai pernyataan Graham [5], bahwa kandungan pati pada buah sukun muda lebih sedikit dibadingkan buah sukun mengkal, karena komposisi pati sukun berubah seiring dengan kematangan buah [22].

\subsubsection{Organoleptik}

Hasil pengamatan organoleptik menunjukkan pati buah sukun muda dan mengkal keduanya merupakan serbuk halus dengan warna putih, tidak berasa, dan berbau khas sukun.

\subsubsection{Bentuk dan distribusi ukuran partikel}

Bentuk mikroskopik dari pati buah sukun muda dan mengkal dapat dilihat pada Gambar 1. Dari Gambar 1 terlihat kedua pati memiliki bentuk yang sama, yaitu speris dan tidak beraturan. Hasil pengukuran dari 300 partikel pati sukun buah muda memiliki ukuran yang lebih besar 
Tabel 1. Hasil analisis fisika pati sukun

\begin{tabular}{|c|c|c|}
\hline Parameter & Pati sukun buah muda & Pati sukun buah mengkal \\
\hline Rendemen (\%) & $\overline{4,3}$ & 8,93 \\
\hline Organoleptik & $\begin{array}{l}\text { serbuk halus, warna putih, } \\
\text { tidak berasa dan berbau khas } \\
\text { sukun }\end{array}$ & $\begin{array}{l}\text { serbuk halus, warna putih, tidak } \\
\text { berasa dan berbau khas sukun }\end{array}$ \\
\hline Bentuk partikel & speris tidak beraturan & speris tidak beraturan \\
\hline Ukuran rata-rata partikel $(\mu \mathrm{m})$ & 26,06 & 5,65 \\
\hline $\mathrm{pH}$ & $6,03 \pm 0,12$ & $5,62 \pm 0,14$ \\
\hline Kadar air (\%) & 14,1 & 19,70 \\
\hline $\begin{array}{cl}\text { Kerapatan }(\mathrm{g} / \mathrm{ml}): \\
\text { - } & \text { sejati } \\
\text { - } & \text { nyata } \\
\text { - } & \text { mampat }\end{array}$ & $\begin{array}{l}1,388 \pm 0,050 \\
0,319 \pm 0,004 \\
0,460 \pm 0,005\end{array}$ & $\begin{array}{l}1,252 \pm 0,152 \\
0,353 \pm 0,0057 \\
0,506 \pm 0,025\end{array}$ \\
\hline Kadar pemampatan (\%) & $30,63 \pm 0,70$ & $29,19 \pm 3,16$ \\
\hline Rasio Hausner & $1,44 \pm 0,015$ & $1,40 \pm 0,061$ \\
\hline Kecepatan alir (g/detik) & $0,458 \pm 0,062$ & $0,434 \pm 0,019$ \\
\hline Sudut istirahat $\left({ }^{\circ}\right)$ & $35,67 \pm 3,26$ & $42,05 \pm 3,21$ \\
\hline $\begin{array}{cl}\text { Viskositas (Cps): } \\
\text { - } & 5 \% \\
\text { - } & 10 \% \\
\text { - } & 15 \%\end{array}$ & $\begin{array}{l}3.000 \\
22.800 \\
36.800\end{array}$ & $\begin{array}{l}7.500 \\
54.333 \\
167.667\end{array}$ \\
\hline
\end{tabular}

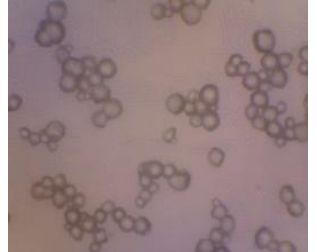

(a)

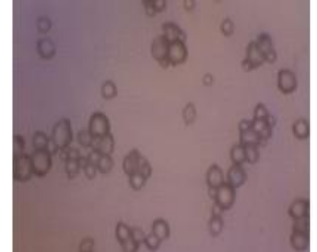

(b)
Gambar 1. Bentuk mikroskopik pati sukun buah muda (a) dan buah mengkal (b); Perbesaran: 100 kali

dari pati buah sukun mengkal, yakni $26,06 \mu \mathrm{m}$, sedangkan pati buah sukun mengkal 5,65 $\mu \mathrm{m}$.

\subsection{4. $\mathrm{pH}$}

Tabel 1 memperlihatkan bahwa pati buah sukun muda memiliki pH 6,03, sedangkan pati buah sukun mengkal 5,62. Hasil ini sesuai dengan pustaka yang menyatakan bahwa $\mathrm{pH}$ dispersi pati berkisar antara 4,0 - 8,0 [7].

\subsubsection{Kadar air}

Penetapan kadar air yang dilakukan dengan moisture balance diperoleh hasil untuk pati buah sukun muda sebesar 14,1\% dan untuk buah mengkal 19,70\%. Menurut Baines and Seal [23], dalam kondisi atmosfer normal, pati mengandung kadar air antara 10-20\%, sehingga kadar air yang diperoleh telah memenuhi persyaratan.

\subsubsection{Kerapatan}

Hasil uji kerapatan sejati, kerapatan nyata, dan kerapatan mampat menunjukkan nilai masingmasing 1,388 g/ml, 0,319 mg/ml, dan 0,460 mg/ $\mathrm{ml}$ untuk pati buah muda, sedangkan untuk pati buah mengkal diperoleh hasil 1,252 g/ml, 0,353 $\mathrm{g} / \mathrm{ml}$, dan 0,506 g/ml. Hasil ini serupa dengan hasil penelitian Adebayo et al. [9], yaitu 1,472 g/ $\mathrm{ml}$ untuk kerapatan sejati, $0,324 \mathrm{~g} / \mathrm{ml}$ untuk kerapatan nyata, dan $0,511 \mathrm{~g} / \mathrm{ml}$ untuk kerapatan mampat.

\subsubsection{Laju alir, sudut istirahat, dan rasio Hausner}

Sifat alir pati sukun ditentukan dengan beberapa metode, yaitu: kecepatan alir, sudut istira- 
Tabel 2. Hasil analisis fisika pati sukun

\begin{tabular}{lll}
\hline Parameter & Pati sukun buah muda & Pati sukun buah mengkal \\
\hline Pati total (\%) & $87,33 \pm 0,18$ & $84,28 \pm 0,78$ \\
Amilosa (\%) & $63,54 \pm 0,05$ & $68,26 \pm 0,01$ \\
Amilopektin (\%) & $23,79 \pm 0,23$ & $16,02 \pm 0,79$ \\
\hline
\end{tabular}

Keterangan: nilai merupakan rerata \pm SD $(n=3)$

hat, rasio Hausner, dan kadar pemampatan. Suatu serbuk dikatakan mengalir dengan baik jika memiliki kecepatan aliran $\geq 10 \mathrm{~g} /$ detik, sudut istirahat $31-35^{\circ}$, rasio Hausner 1,12-1,18 dan kadar pemampatan 11-15\% [15]. Dari Tabel 1 terlihat pati buah sukun muda memiliki kecepatan alir $0,458 \mathrm{~g} /$ detik, dengan sudut istirahat $35,67^{\circ}$, dan rasio Hausner 1,44 serta kadar pemampa$\tan 30,63 \%$, yang semuanya menunjukkan bahwa pati buah sukun muda memiliki aliran yang buruk; demikian pula dengan pati buah sukun mengkal dengan kecepatan alir 0,434 g/detik, sudut istirahat $42,05^{\circ}$, rasio Hausner 1,40 serta kadar pemampatan $29,19 \%$.

\subsubsection{Viskositas}

Pada Tabel 1 terlihat semakin tinggi konsentrasi, semakin tinggi viskositas. Hal ini sesuai dengan pustaka yang menyatakan bahwa viskositas pati bersifat dinamis [7]. Viskositas pada pati terbentuk ketika suspensi pati dalam air dipanaskan, yang mengakibatkan daya tarik-menarik antara molekul air lebih kuat daripada antar molekul pati, sehingga air akan terserap dan partikel pati membengkak. Masuknya air ke dalam granul pati akan meningkatkan viskositas suspensi pati $[24,25,26]$.

\subsection{Hasil analisis kimia pati sukun}

Pati tersusun atas dua komponen utama, yakni amilosa dan amilopektin. Perbandingan amilosa dan amilopektin akan mempengaruhi sifat kelarutan, daya serap air dan derajat gelatinisasi dari pati. Semakin tinggi kandungan amilosa di dalam pati, maka pati lebih kering dan kurang lengket; sebaliknya, semakin tinggi kandungan amilopektin dalam pati, maka pati cenderung sedikit me- nyerap air dan menjadi lebih lengket [27].

Analisis kimia pati buah sukun dikakukan dengan menetapkan kadar pati total, kadar amilosa, dan kadar amilopektin. Hasil analisis kimia pati buah sukun dapat dilihat pada Tabel 2 .

Hasil analisis kimia memperlihatkan pati buah sukun muda mengandung pati total lebih banyak (87,33\%) dibandingkan dengan pati buah yang mengkal $(84,28 \%)$, namun hasil ini masih lebih rendah dari hasil penelitian Adewusi et al. [28], yaitu sebesar 98,64\%. Perbedaan ini kemungkinan disebabkan adanya perbedaan spesies dan tempat tumbuh. Adewusi et al. [28] meneliti buah sukun jenis Artocarpus communis Fors. yang berasal dari Nigeria Barat Daya, sedangkan pada penelitian ini menggunakan spesies Artocarpus altilis yang berasal dari Kabupaten Bone, Sulawesi Selatan.

Hasil analisis kimia juga menunjukkan bahwa kedua pati memiliki kandungan amilosa yang lebih besar daripada kandungan amilopektinnya. Ini menunjukkan bahwa pati sukun bersifat kering dan kurang lengket atau sukar menggelatinasi [27], karena molekul amilosa cenderung berada dalam posisi sejajar, sehingga gugus-gugus hidroksilnya dapat berikatan dengan bebas dan pati akan membentuk kristal agregat yang kuat [29, 30]. Untuk itu, kedua pati sukun ini direkomendasikan untuk digunakan sebagai bahan penghancur pada sediaan tablet konvensional [31].

\section{Kesimpulan}

Pati buah sukun muda dan mengkal masingmasing memiliki rendemen 4,3\% dan 8,93\%, berupa serbuk halus berwarna putih, tidak be- 
rasa, dan berbau khas sukun, bentuk speris tidak beraturan, dengan ukuran partikel rata-rata $26,06 \mu \mathrm{m}$ dan 5,69 $\mu \mathrm{m}$. Analisis sifat fisika memperlihatkan bahwa kedua pati memiliki $\mathrm{pH}$, kadar air, dan kerapatan yang sesuai pustaka, sifat alir yang buruk, dengan viskositas yang memperlihatkan bahwa semakin tinggi konsentrasi pati semakin meningkat viskositasnya. Hasil analisis kimia menunjukkan bahwa kedua pati memiliki kadar amilosa yang lebih tinggi dibandingkan kadar amilopektinnya, sehingga direkomendasikan untuk digunakan sebagai bahan penghancur pada sediaan tablet konvensional.

\section{Daftar Pustaka}

1. Badan Pusat Statistik. Data produksi komoditas sukun berdasarkan lokasi provinsi tahun 2018. Online. www.bps.go.id, diakses 25 Oktober 2019.

2. Rahman S. Membangun pertanian dan pangan untuk mewujudkan kedaulatan pangan. Yogyakarta: Deepublish Publisher; 2018.

3. Ragone D. Breadfruit. Artocarpus altilis (Parkinson) Fosberg. The international plant genetics resources institute.1997: 26.

4. Halley PJ, Averous A. Starch polymers. San diego: Elsevier BV; 2014.

5. Graham HD, de Bravo NE.Composition of the breadfruit. Journal of Food Science. 1981;46(2):535-9.

6. Suprapti L. Teknologi tepat guna: Tepung sukun. Yogyakarta: Kanisius; 2002.

7. Rowe RC, Sheskey PJ, and Quinn ME. Handbook of pharmaceutical excipients. $6^{\text {th }}$ Edition. New York: Pharmaceutical Press and American Pharmacists Association; 2009.

8. Gunaratne A, Corke H. Starch: Analysis of quality. in Encyclopedia of Food Grains. Boulevard: Elsevier Ltd.; 2016.

9. Adebayo SA, Brown-Myrie E, Itiola OA. Comparative disintegrant activities of breadfruit and official corn starch. Powder Technology. 2008;181(2):98-103.

10. DepKes RI. Farmakope Herbal Indonesia. Edisi 1. Jakarta: KeMenKes RI; 2008.

11. DitJen POM. Farmakope Indonesia. Edisi 5. Jakarta: KeMenKes RI; 2015.
12. Filho WL, Mannke F, Mohee R, Schulte V, Surroop D. (Eds). Climate-smart technologies. London: Springer Science \& Business Media; 2013.

13. Wrolstad RE, Acree TE, Decker EA, Penner MH, Reid DS, Schwartz SJ, Shoemaker CF, Smith DM, Sporns P. Handbook of food analytical chemistry. Volume 1: Water, protein, enzymes, lipids, and carbohydrates. New York: John Wiley \& Sons, Inc; 2005.

14. Jain GK, Ahmad FJ, Khar RK. Theory and practice of practice of physical pharmacy. New Delhi: Elsevier; 2012.

15. United Pharmacopeial Convention. The united states pharmacopeia. $30^{\text {th }}$ ed. Rockville: United Pharmacopeial Convention, Inc.; 2007.

16. Subroto E, Jeanette G, Meiyanasari Y, Luwinsky I, Baraddiaz S. Review on the analysis methods of starch, amylose, amylopectinin food and agricultural products. International Journal of Emerging Trends in Engineering Research. 2020;8(7):3519-24.

17. Niken A, Adepristian D. Isolasi amilosa dan amilopektin dari pati kentang. Jurnal Teknologi Kimia dan Industri. 2013;2(3):57-62.

18. Jarvis CA, Walker JR. Simultaneous, rapid, spectrophotometric determination of total starch, amylose and amylopectin. J. Sci Food Agric. 1993;63:53-7.

19. William PC, Kuzina FD, Hlynka I. A Rapid colorimetric procedure for estimating the amylose content of starches and flours. Cereal Chemistry. 1970;4:411-21.

20. Bos CE, Bolhuis GK, Van Doorne H, Lerk CF. Native starch in tablet formulations: Properties on compaction. Pharmaceutisch Weekblad. 1987;9(5):274-82.

21. Odeku OA. Potentials of tropical starches as pharmaceutical excipients: A review. Starch/stärke. 2013;65:89-106.

22. Wootton M, Tumaalii F. Composition of flours from Samoan Breadfruit. Journal of Food Science.1984;49(5):1396-7.

23. Baines D, Seal R. Natural food additives, ingredients and flavourings. United Kingdom: Woodhead Publishing; 2012.

24. Iskandar S. Ilmu kimia teknik. Yogyakarta: Deepublish; 2015. 
25. Winarno FG. Kimia pangan dan gizi. Jakarta: Gramedia Pustaka Utama; 1991.

26. Aini N, Purwiyatno H. Gelatinization properties of white maize starch from three varieties of corn subject to oxidized and acetylated-oxidized modification. International Food Research Journal. 2010;17(4):961-8.

27. Setiarto RHB. Teknologi pengemasan pangan antimikroba yang ramah lingkungan. Jakarta: Guepedia; 2020.

28. Adewusi SRA, Udio J, Osuntogun BA. Studies on the carbohydrate content of breadfruit (Artocarpus communis Forst) from South-Western Nigeria.
Starch-stärke.1995;47(8):289-94.

29. Liu Z, Han JH. Film-forming characteristics of starches. Journal of Food Science. 2005;70(1):E31-6.

30. Susi, Agustina L, Wibowo C. A preliminary study on the rehydration characteristics and cooking time of analog rice from the formulation of modified nagara bean flour through $L$. plantarum fermentation and sago starch. IOP conf. Series: Earth environmental science. 2019;255(1):012013.

31. Schwartz JB, Zielinski JA. The binding and disintegrant properties of the corn starch fractions: Amylose and amylopectin. Drug Development and Industrial Pharmacy.1978;4(5):463-83. 